\title{
PRRX1 wt Allele
}

National Cancer Institute

\section{Source}

National Cancer Institute. PRRX1 wt Allele. NCI Thesaurus. Code C98031.

Human PRRX1 wild-type allele is located in the vicinity of 1q24 and is approximately $76 \mathrm{~kb}$ in length. This allele, which encodes paired mesoderm homeobox protein 1, is involved in the regulation of muscle creatine kinase expression. 